\title{
DIVERSITY OF UNDERGROWTH IN AREN (ARENGA PINNATA MERR.)
}

\author{
Naemah Dina ${ }^{1 *}$, Rachmawati Normela ${ }^{1}$, Sidik Abdurrahman ${ }^{2}$ \\ ${ }^{1}$ Department of Forestry Science, Faculty of Forestry, University of Lambung Mangkurat, \\ South Kalimantan, Indonesia \\ ${ }^{2}$ Degree Program of Department of Forestry Science, Faculty of Forestry, \\ University of Lambung Mangkurat, South Kalimantan, Indonesia \\ *E-mail: dina.naemah@ulm.ac.id
}

\begin{abstract}
The condition of plant communities is closely related to various factors contained in an area such as edaphic, climatic and biological factors. The composition of the planted area is strongly influenced by the composition of plant species, dominant species, density and state of canopy closure. Plants that grow in hilly areas with relatively high and evenly distributed rainfall throughout the year. In South Kalimantan this species grows around people's residences and plantation areas. Sugar palm plantations (Arenga pinnata Merr.) have a fairly humid environmental condition and at the top of the garden will be very rich in various types of undergrowth so it is very interesting to make an inventory of both species and diversity. By using vegetation analysis that makes several sample plots with a size of $1 \mathrm{~m} \times 1 \mathrm{~m}$ in a large plot of $10 \mathrm{~m} \times 10 \mathrm{~m}$ so that they can represent the research location. Observing all types of undergrowth and documenting each type so that its diversity index and dominant nature can be known. The results showed that the number of $P$ species in question was 17 species from 11 families, with several dominant species such as Litu ( $L$. scandens), Cambai ( $P$. baccatum Blume), Magatseh ( $P$. polyneura) and ( $P$. pubinerve) as well as the Diversity index value $\left(\mathrm{H}^{\prime}\right)$ of 3.39 .
\end{abstract}

\section{KEY WORDS}

Arenga pinnata dominance, undergrowth, diversity, weeds.

Undergrowth is a type of basic vegetation found under forest stands, including grasses, herbs, shrubs and ferns. Some types of undergrowth can be used for various purposes such as food, medicine and ornamental plants. Not infrequently also undergrowth plants can act as weeds that inhibit the growth of tree regeneration, especially in monocultures that are cultivated. The competitive power of undergrowth plants has the characteristics of growing quickly, high tolerance for environmental factors, great breeding power both generatively and vegetatively.

From another perspective, the existence of undergrowth communities is a very important component of biodiversity to be conserved, because it has several values such as existence value, aesthetics, environmental service value, heritage value, consumptive value and productive value. Vegetation analysis is a study of plant communities or a way to study the composition (composition of species) and structure of vegetation (form of plant communities) in an area. With vegetation analysis can be obtained quantitative information about the structure and composition of a plant community.

Sugar palm (Arenga pinnata Merr.) is a type of non-timber forest product that can be found in tropical rain forests and dry forests, and is quite common in South Kalimantan, Indonesia. Palm trees grow in hilly areas with relatively high and evenly distributed rainfall throughout the year. In South Kalimantan this species grows around people's residences and plantation areas and is a plant that has not been cultivated. Sugar palm plants are very useful for people's lives, because almost all parts of the plant such as leaves, stems, fibers, fruit, sap and roots can be used for various needs.

The palm tree as a member of the ecosystem is certainly very closely related to the undergrowth around the place where it grows and interacts with each other so that the uniqueness of the environment certainly affects the types of undergrowth around it. Until now 
there is no data and research that identifies the types of undergrowth under and around the palm trees, so this study aims to identify the types of undergrowth around the sugar palm stands.

\section{METHODS OF RESEARCH}

This research was conducted in Banjar district, Indonesia in the area of Arenga pinnata Merr. Using several equipments such as rope, measuring tape, tallysheet, camera, GPS, sample paper bag, type identification module. Data were collected using the vegetation analysis method by taking plant samples in a $1 \mathrm{~m} \times 1 \mathrm{~m}$ circular plot in a $10 \mathrm{~m} \times 10 \mathrm{~m}$ large plot. with a distance between lanes of $10 \mathrm{~m}$. Species diversity $\left(\mathrm{H}^{\prime}\right)$ was determined using the Shanon-Wiener formula (Odum, 1998) in. Abdiyani (2008), namely:

$$
\mathrm{H}^{\prime}=-\sum_{\mathrm{i}=1}^{S}\left(\frac{n i}{N}\right) \ln \left(\frac{n i}{N}\right)
$$

Where: $\mathrm{H}^{\prime}$ - diversity index; $\mathrm{s}$ - number of types; $\mathrm{ni}$ - the number of individuals of type I; $\mathrm{N}$ the number of individuals of all types.

\section{RESULTS AND DISCUSSION}

The undergrowth species in the research plot were identified as many as 17 species belonging to 11 families (Table 1). The Piperaceae family is the undergrowth that has the most species (Figure 1). The piperaceae family has a distinctive leaf shape and is sometimes accompanied by a distinctive aroma, this type is undergrowth that has sticky roots so that it can grow vines, it can also be a shrub or shrub. The diversity of Piper species in Indonesia is still small compared to the total number of Piper species found in the world, which is around 2,658 (The Plant List 2013) in Munawaroh (2017).

Table 1 - Types of Lower Plants around Sugar Palm Stands (A. pinnata)

\begin{tabular}{llll}
\hline No. & Local Name & Botanical Name & Family \\
\hline 1 & Bengkudu Hutan & Morinda $s p$. & Rubiaceae \\
\hline 2 & Buta-Buta Lalat & Piper $s p$ & Piperaceae \\
\hline 3 & Cambai & Piper baccatum Blume & Piperaceae \\
\hline 4 & Carikan & Piper aduncum L & Piperaceae \\
\hline 5 & Jambu Burung & Eugenia sp & Myrtaceae \\
\hline 6 & Jarum-jarum & Saraca asoca & Fabaceae \\
\hline 7 & Keladi Belah & Amydrium $s p$ & Araceae \\
\hline 8 & Keladi Hutan & Caladium sp & Araceae \\
\hline 9 & Kopi Hutan & Fagraea recenosa & Gentianaceae \\
\hline 10 & Lirik & Phrynium pubinerve & Marantaceae \\
\hline 11 & Litu & Lygodium scandens & Lygodiaceae \\
\hline 12 & Magatseh & Parameria polyneura & Apocynaceae \\
\hline 13 & Nanangkaan & Ludwigia sp. & Onagraceae \\
\hline 14 & Paku Hutan & Lygodium salicifolium & Lygodiaceae \\
\hline 15 & Rumput Teratat & Lopatherum gracile & Poaceae \\
\hline 16 & Sapit Undang & Canthium sp & Rubiaceae \\
\hline 17 & Sarapangan & Eleusine indica & Poaceae \\
\hline
\end{tabular}

Piper baccatum is a type of betel nut plant with the appearance of oval, heart-shaped leaves with a green color, the surface of the leaves is bald and the leaf bones are quite clear. Research conducted by Uy et.al. (2015) on this species showed that the extract and boiled water of $P$. baccatum had a chance as a candidate for antioxidants due to the presence of toxic bioactivity in the experiment. Another piper family is $P$. aduncum which has slightly oval leaves with slightly pointed ends, pinnate leaves with slightly hairy petioles. Found in tiers of 
size, seedlings do not propagate, allowing the species to grow as woody shrubs. In an in vitro study, P. aduncum leaf extract had good microbial activity where the content contained in the extract showed antifungal and antibacterial activity (Oukunade, 1997).

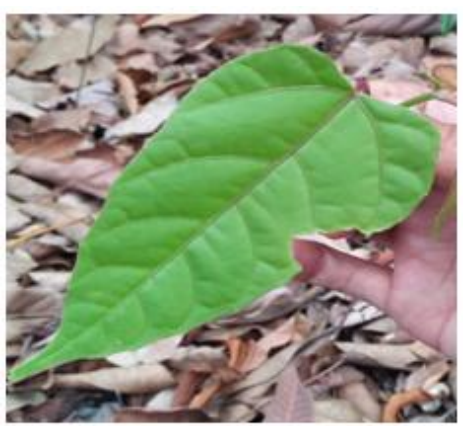

(a)

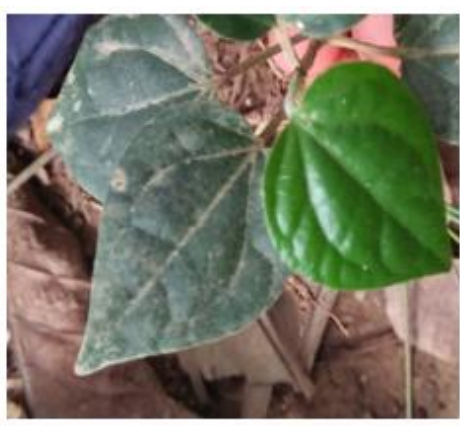

(b)

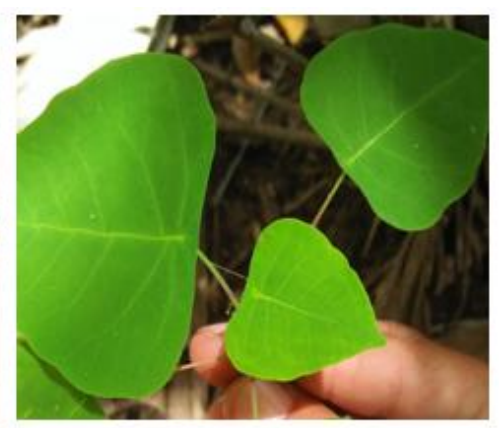

(c)

Figure 1 - Piperaceae family (a) Carikan; (b) Cambai; (c) Buta buta lalat

The most common species found in the field and almost always found in every observation plot were Litu ( $L$. scandens), Cambai ( $P$. baccatum Blume), Magatseh ( $P$. polyneura) and Lirik ( $P$. pubinerve) species (Figure 2). The Litu plant is a type of fern and is a medicinal plant. This plant is commonly used by the Dayak Paser (East Kalimantan) and Dayak Amandit (South Kalimantan) communities, according to community information; it can be used as a postnatal recovery medicine (Noorcahyati 2012). The roots are embedded in the soil in the form of brown fibers with long rhizome segments that can be used as a toothache medicine, by using boiled water as a substitute for water when gargling (Hasibuan et al 2016).

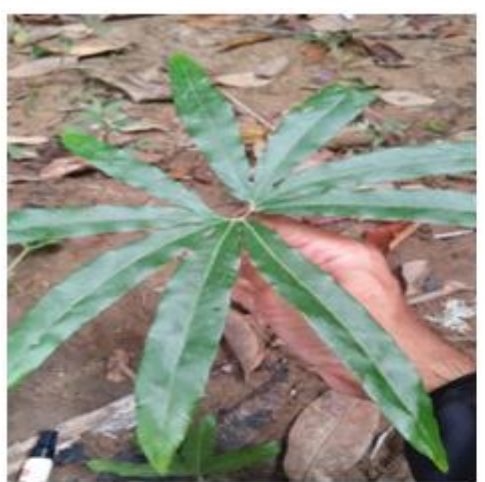

(a)

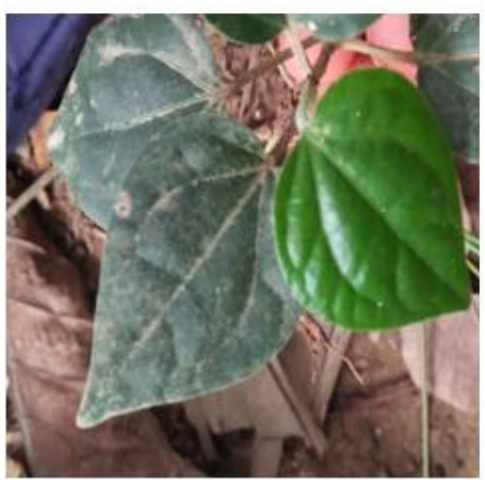

(c)

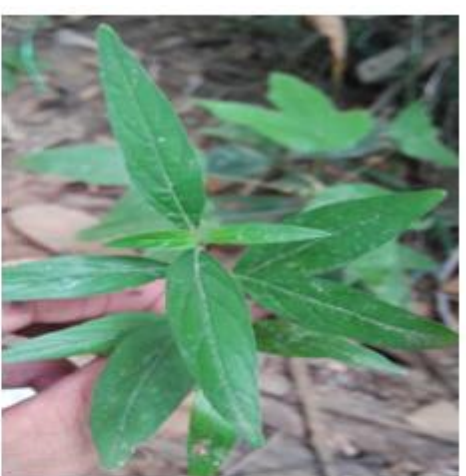

(b)

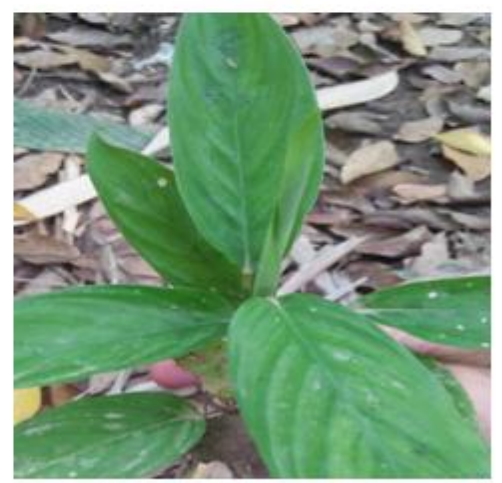

(d)

Figure 2 - Types of dominant undergrowth (a) Litu; (b) Magatseh; (c) Cambai; (d) Lirik 
Magatseh leaves ( $P$. polyneura Hook $f$ ) in a study conducted by Sari et. al. (2015) can be used to treat female organ problems by the Sanggau Dayak community, as well as research conducted by Falah and Norcahyati (2017) which states that the magatseh plant can strengthen vaginal muscles through boiled root water that is drunk regularly. This shows that the types of plants that are around this palm plant have the opportunity to be investigated further to determine the chemical content associated with the efficacy felt by some people.

Another species that also dominates the research plot is $P$. pubinerve, leaf extract of $P$. pubinerve at a certain dose according to the research of Mamuaya et.al. (2017) can overcome high blood glucose levels, while the essential oil content of this type of leaf has antioxidant and antimicrobial potential where the antimicrobial activity is quite large against pathogenic bacteria and spoilage organisms (Li, Ren et al. 2015), so it can be used as natural antioxidant and antimicrobial agent for the packaging and medical food industry.

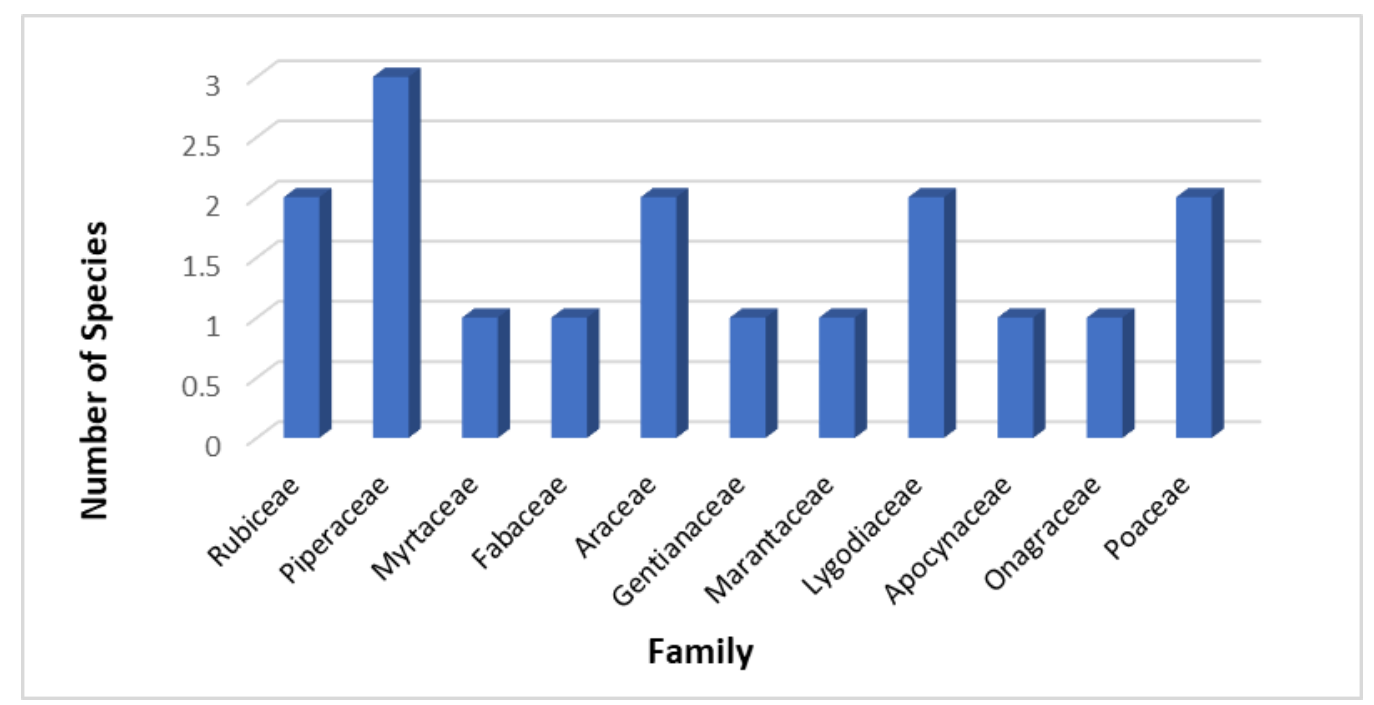

Figure 3 - Number of undergrowth species in the family

From the results of the identification of undergrowth species around the sugar palm, 11 families were obtained, each of which has one to three species (Figure 3). The largest family of Piperaceae with three species, the Rubiaceae family, which is a family of flowering plants, can be in the form of shrubs, lianas or trees. The rubiaceae family contains about 13,500 species in 611 genera, making it the fourth largest angiosperm family. The greatest diversity of species is concentrated in the (sub) tropics (https://mimirbook.com/id/). Another family is Araceae, which is a type of taro which is very common in Indonesia with wet trunk characteristics, living in a humid and protected place. It grows herbaceous and some propagates, some are found in a slightly dry place. At this time the Araceae family is being hunted because it can be used as an ornamental plant and has high selling value with its unique shape and color.

The diversity of undergrowth around the A. pinnata Merr. is 3.39, this of course is strongly influenced by the number of species in the area of the research plot. The diversity index describes the level of stability in a community; the level of vegetation diversity is influenced by the number of individuals in each species (Naemah et.al, 2020). The diversity of species that make up the plant community in a place is the result of the interaction of several factors, the time factor, the diversity of species in a plant community is the result of evolution, spatial heterogeneity, the plant community formed is strongly influenced by the existing environment Environmental factors that greatly affect the diversity of vegetation includes altitude, air humidity, air temperature and the intensity of sunlight. These environmental factors affect the distribution of plant species and their growth (Destaranti et al. 2017). 


\section{CONCLUSION}

The results of the identification of the undergrowth around the $A$. pinnata Merr. there are 17 species from 11 families with the diversity index of undergrowth species is 3.39.

\section{ACKNOWLEDGMENTS}

The gratitude is conveyed to LPPM ULM for funding research through PDWM scheme and fellow students who helped with field survey activities.

\section{REFERENCES}

1. Abdiyani, S. (2008). Keanekaragaman jenis tumbuhan bawah berkhasiat obat di dataran tinggi Dieng. Jurnal Penelitian Hutan and Konservasi Alam, 5(1), 79-92.

2. Destaranti, N., Sulistyani, S., \& Yani, E. (2017). Struktur and Vegetasi Tumbuhan Bawah pada Tegakan Pinus di RPH Kalirajut and RPH Baturraden Banyumas. Scripta Biologica, 4(3), 155-160.

3. Falah, F., \& Hadiwibowo, N. (2017). Species identification of traditional medicine plants for women's health in East Kalimantan: lesson learned from local wisdom. Indonesian Journal of Forestry Research, 4(1), 49-67.

4. Hasibuan, H., \& Rizalinda, E. R. P. (2016). Inventarisasi jenis paku-pakuan (Pteridophyta) di hutan sebelah darat Kecamatan Sungai Ambawang Kalimantan Barat. Protobiont, 5(1).

5. Li, R., Hu, H.-B., Li, X.-F., Zhang, P., Xu, Y.-K., Yang, J.-J., \& Wang, Y.-F. (2015). Essential oils composition and bioactivities of two species leaves used as packaging materials in Xishuangbanna, China. Food control.

6. Mamuaya, T., Pakasi, F. G., \& Tumbol, M. V. (2017). Antidiabetic Activity Of Ethanol Extract Of Phrynium Pubinerve Blume Leaf In Alloxan-Induced Diabetic Rats (Rattus Norvegicus). Paper Presented at the Proceeding Manado Health Polytechnic 1st International Conference. ISSN: 2599-2031.

7. Munawaroh, E. (2017). The Diversity and Conservation of Piper (Piperaceae) in Bukit Barisan Selatan National Park, Lampung Province. Media Konservasi, 22(2), 118-128.

8. Naemah, D., Rachmawati, N., \& Pujawati, E. D. (2020). Keragaman Jenis Tumbuhan Bawah Hutan Rawa Gambut Di Kabupaten Banjar. Jurnal Hutan Tropis, 8(3), 298-305.

9. Noorcahyati, S. (2012). Tumbuhan Berkasiat Obat Etnis Asli Kalimantan. Balai Penelitian Teknologi Konservasi Sumber Daya Alam: Balikpapan.

10. Okunade, A. L., Hufford, C. D., Clark, A. M., \& Lentz, D. (1997). Antimicrobial properties of the constituents of Piper aduncum. Phytotherapy Research: An International Journal Devoted to Medical and Scientific Research on Plants and Plant Products, 11(2), 142-144.

11. Sari, A., Linda, R., \& Lovadi, I. (2015). Pemanfaatan Tumbuhan Obat Pada Masyarakat Suku Dayak Jangkang Tanjung Di Desa Ribau Kecamatan Kapuas Kabupaten Sanggau. Protobiont, 4(2). Abrori, M. 2016.

12. Uy, M. M., \& Villanueva, M. P. (2015). The brine shrimp lethality of the leaf extracts of Piper baccatum Blume and their antioxidant properties. Asian Journal of Biological and Life Sciences, 4(3). 